\title{
Politics AND Constitutional LaW: A Distinction WITHOUT A DifFERENCE?
}

\author{
Robert J. McKeever*
}

\begin{abstract}
This article examines the relationship between Politics and Law in U.S. Supreme Court decision-making. It argues that three major developments in recent decades have combined to undermine the Court's status as a legal and judicial institution, and instead define it as political actor, motivated by ideology and the personal policy predilections of the Court's Justices. The first of these elements is the increasingly political and partisan nature of the Supreme Court appointment process, as witnessed by the recent Gorsuch and Kavanaugh nominations. The behaviour of the President and Senators in these controversial appointments conclusively demonstrates that the country's leading politicians view the Court as primarily a political body rather than a legal one. The second element of the assault on the Court's status as a judicial institution is the rise in influence of the behaviouralist school of Supreme Court analysis. Beginning with the work of academics such as Glendon Schubert, the behaviouralists employed new methods and theories in an attempt to debunk the Legal Model of Supreme Court decision-making and to replace it with what is known today as the Attitudinal Model. It forcibly argues that Supreme Court Justices are political in intent and decision, with legal language and arguments being no more than judicial camouflage to disguise their true nature. This applies equally to both conservative and liberal justices. The article identifies the third element of the assault on the status of the Court as a legal institution as coming from Originalist scholars, activists and judges who accuse liberal Justices of having abandoned traditional interpretive methods in favour of redefining the language of the Constitution to suit their progressive political agenda. Originalists acknowledge that their own interpretive methods may lead to results deemed unacceptable to contemporary Americans, but argue that it the duty of the political branches of government, not the courts, to modernise policy and practice. This article concludes that while Originalism has genuine appeal as a theory of interpretation, it is nevertheless both impractical and undesirable. Moreover, rather than returning the Court to the Legal Model, the Originalist campaign has only served to persuade many that the Attitudinal Model is an accurate one. However, the article also argues that the break with Originalism by the Warren Court over segregation has developed into a wholesale change in the Court's role in American government, one that ill-becomes the unelected judiciary in a representative democracy. It is argued here that the best way to restore the legal and judicial identity of the Court would be a return to the emphasis on 'judicial role', once championed by great jurists such as Learned Hand, Oliver Wendell Holmes, Louis Brandeis and John Harlan II. Judicial modesty and restraint would distinguish the Court from the political branches of American government. The Court should
\end{abstract}

* Associate Fellow, Institute of the Americas, University College, London. This paper was initially prepared as the Keynote Address for the Conference on American Politics, History and Law: A Cross-Disciplinary Dialogue, held at the Centre for American Legal Studies, Birmingham City University, 30 July, 2018. 
decide less and only where the case for a decision of unconstitutionality is very clear and very compelling.

\section{KEYWORDS}

U.S. Supreme Court, Constitutional Interpretation, Judicial Role

\section{CONTENTS}

I. Politics and Partisanship in Supreme Court Appointments......... 403

II. The Attitudinal Model And the Legal Model............................ 405

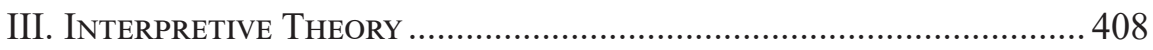

IV. The WARren Court AND Social REForm ...................................... 410

V. Robert Bork AND ORIginalism ................................................. 412

VI. IMPASSE AND A PoSSIBLE WAY ForWARD .......................................... 415 
A 'distinction without a difference' exists where a linguistic or conceptual difference turns out to have no substantial significance and merely masks two similar, if not identical, objects. As applied to constitutional law and interpretation, it means that judges - especially the Justices of the United States Supreme Court - employ the forms and language of law, while their reasoning, motivations and goals are political. As some often say, members of the Supreme Court are properly viewed as "politicians in judges' robes".

Is this assertion accurate? The evidence of the last two nominations to the Supreme Court makes clear that politicians in the United States see constitutional law as highly politicised and critical to public policy on matters of utmost importance - abortion, freedom of religion, elections, gun ownership, race and gender equality, the powers of the Executive Branch in foreign policy and national security and the rights of States against Federal power.

\section{Politics and Partisanship in Supreme Court APPOINTMENTS}

In February 2016, Supreme Court Justice Antonin Scalia died suddenly. The procedure for replacing him, set out in Article II, Section 2 of the US Constitution, is clear: the President is required to nominate a new Justice, but the nominee must be approved by the Senate. However, at this time, several political and partisan factors complicated the nomination and confirmation process. The Democratic President, Barack Obama, was faced with a Republican-controlled Senate. Moreover, Obama was a 'lame-duck' President, meaning he had served two terms and was constitutionally barred from seeking a third in November, 2016.

Secondly, as a result of Scalia's death, the Supreme Court was balanced on a political knife-edge. The eight remaining Justices were divided between four liberals and four conservatives, though one of the latter, Justice Kennedy, sometimes joined the liberals on issues such LGBT equality and the death penalty. If Obama succeeded in appointing another Justice, he would create a decisive and solid fiveJustice liberal majority that would control decisions on the most divisive issues of the day. Moreover, Justice Scalia had been perhaps the most celebrated proponent of the doctrine of Originalism in constitutional interpretation and a conservative icon. He would be replaced by a liberal and originalism and conservatism would be dealt a grievous blow. These were the political and judicial stakes that dominated the process of replacing Justice Scalia.

On the horns of a dilemma, Republican Senate Majority Leader Mitch McConnell made an unprecedented move. He announced: "The American people should have a voice in the selection of their next Supreme Court Justice. Therefore this vacancy should not be filled until we have a new President". ${ }^{1}$ McConnell's attempt to cloak his gambit in democratic principle was, to say the least, ironic. After all, the Founding Fathers had set up a nomination process that deliberately excluded the American people from having a voice in the proceedings by giving the popularly-elected House of Representatives no say in the matter. Realistically, the

\footnotetext{
Harper Neidig, McConnell: Don't Replace Scalia Until After Election, The HiLl, 02/13/16 06:27 PM EST, https://thehill.com/homenews/senate/269389-mcconnelldont-replace-scalia-until-after-election .
} 
Republican party engaged in an entirely politically-motivated, last-ditch attempt to prevent the Supreme Court acquiring a liberal majority. Its last hope was that a Republican candidate would win the presidential election in November, 2016, and be able to replace Scalia with another conservative.

The absence of any principle in McConnell's strategy was confirmed when he reversed his argument when Justice Kennedy announced his retirement from the Court in June 2018. As noted above, Kennedy was regarded as the swing Justice who sometimes joined the four liberals on the Court to create a majority on matters such as gay rights, abortion and the death penalty, although he was usually with the conservative Justices on other issues. If President Trump succeeded in appointing Kennedy's replacement, then there would be a solid five-Justice conservative majority on the Court, thus finally fulfilling the aim of conservatives going back to the presidency of Ronald Reagan. Trump faced a Senate with a narrow Republican majority, but the upcoming mid-term elections of November 2018 could change that. So whereas he had delayed filling the Scalia vacancy for almost a year, McConnell now rushed through President Trump's nomination of Brett Kavanaugh in order to get him confirmed before the mid-term elections and the possibility of a Democrat-controlled Senate. Democrats, equally politically-motivated, did all they could to delay Kavanaugh's confirmation. This culminated in a series of accusations by women, especially Professor Christine Blasey Ford, that Kavanaugh had sexually assaulted them. In the absence of conclusive proof, Kavanaugh was eventually confirmed on an almost wholly partisan basis. ${ }^{2}$

The Kavanaugh hearings were distasteful to many observers. Yet they provided further evidence of the bitter and even toxic nature of the partisan battle to control the Supreme Court. ${ }^{3}$ Anyone observing these political shenanigans could only conclude that the Supreme Court is viewed as a political, not judicial, body by the other principal actors in the American political system.

Given the sharply heightened partisanship in American politics in recent decades, one might be tempted to regard Congressional and Presidential behaviour over Supreme Court appointments as typical of politicians while telling us little about how Justices decide the cases before them. However, academic analyses of Supreme Court decision-making have increasingly concluded that constitutional law and politics are fundamentally one and the same: a distinction without a difference.

2 One Democrat Senator, Joe Manchin of West Virginia, voted to confirm Kavanaugh. One Republican Senator, Lisa Murkowski of Alaska did not, though she 'paired' her vote with an absent Republican Senator who would have voted to confirm. Thus the final vote was 50-48 to confirm.

3 The Kavanaugh nomination was not the first in modern times to display bitter political partisanship. The defeat of Reagan nominee Robert Bork in 1987 was an epic battle. The narrow confirmation of George H. Bush nominee Clarence Thomas in 1991 involved unsavoury elements similar to those in the Kavanaugh controversy. See, ETHAN Bronner, Battle for Justice: How the Bork Nomination Shook America (2007); Jane Mayer \& Jill Abramson, Strange Justice: The Selling of Clarence Thomas ( 1994); Jan Crawford Greenburg, Supreme Conflict: The Inside Story of the Struggle for Control of the United States Supreme Court (2007). 


\title{
II. The Attitudinal Model AND the Legal Model
}

Beginning in the 1960s, the behaviouralist theory pioneered by Glendon Schubert and others argued that constitutional disputes were a means by which judges could implement their preferred policy choices. Employing statistical methods, such as unidimensional scalogram analysis, Schubert 'predicted' the votes of Supreme Court Justices, although 'predict' must be placed in inverted commas, since he in fact worked backwards. Cases were retrospectively translated into policy choices and each Justice's votes on them were scaled for policy consistency.

Two things about Schubert's approach are worth emphasising here. First, he explicitly states that Supreme Court Justices are political, not legal or judicial, in their intentions. As he wrote, "The Justices themselves are goal oriented and their basic goals are the same as those that motivate other political actors". ${ }^{4}$

The second is that Schubert completely dismisses the written Opinions of Justices in cases and focuses exclusively on their votes. All the constitutional analysis, examination of precedents and institutional powers is irrelevant: "In our analysis, cases before the Supreme Court for decision are treated as questions before the Justices, who are respondents. The Justices respond not by the words they use in their opinions, but by the ways in which they vote". ${ }^{5}$ For Schubert and the behaviouralists, there is no law in Supreme Court decision-making, only politics and policy preferences.

The work of the behaviouralists was taken on and developed by those who argue for the Attitudinal Model of Supreme Court decision-making. Most closely associated with this approach are Jeffrey A. Segal and Harold J. Spaeth, who wrote:

\begin{abstract}
This model holds that the Supreme Court decides disputes in the light of the facts of the case vis-à-vis the ideological attitudes and values of the justices. Simply put, (William) Rehnquist votes the way he does because he is extremely conservative; (Thurgood) Marshall voted the way he did because he was extremely liberal. ${ }^{6}$
\end{abstract}

Segal and Spaeth employed more, and more sophisticated, statistical methods than Schubert, but their conclusions were basically the same: politics and personal policy preference explain Supreme Court decisions. They explicitly contrast their approach with what they term the Legal Model, which they dismiss as serving "only to rationalise the Court's decisions and to cloak the reality of the Court's decision-making process".?

Until the mid-twentieth century, the Legal Model was the widely accepted understanding of Supreme Court decision-making as a process of Law, not Politics. A classic statement of the Legal Model's conception of constitutional interpretation was articulated by Justice Owen Roberts in U.S. v. Butler (1936). At the time of the

4 Glendon Schubert, Judicial Policy-Making: The Political Role of the Courts 164 (Rev'd. ed. 1974).

5 Glendon Schubert, Quantitative Analysis of Judicial Behaviour 293 (1960).

6 Jefrrey A. Segal \& Harold J. Spaeth, The Supreme Court and the Attitudinal Model Revisited 86 (2002).

$7 \quad I d$. at 53 . 
decision, the Court was mired in political controversy as it struck down several key measures of President Franklin Delano Roosevelt's New Deal. At issue in Butler was the federal Agricultural Adjustment Act of 1933, the Roosevelt administration's major initiative to regulate farm production and boost farmers' incomes. However, it was challenged before the Court as an unconstitutional exercise of Congressional power. The Tenth Amendment to the Constitution, it was argued, reserved the power to regulate agriculture to the several States and thus Congress had no power to act on the matter.

A 6-3 majority of the Justices agreed with the challenge. Justice Roberts anticipated the furore that would greet the Court's decision. He emphasised that, like all constitutional decisions, it involved no act of political will on the part of the Justices and was based on impartial, legal analysis:

It is sometimes said that the Court assumes the power to overrule or control the action of the people's representatives. This is a misconception. The Constitution is the supreme law of the land ordained and established by the people. All legislation must conform to the principles it lays down. When an Act of Congress is appropriately challenged in the courts as not conforming to the constitutional mandate, the judicial branch of the government has only one duty - to lay the article of the Constitution which is invoked beside the statute which is challenged and to decide whether the latter squares with the former. All the Court does or can do is to announce the Court's considered judgement upon the question. The only power it has, if such it may be called, is the power of judgment, This Court neither approves nor condemns any legislative policy. ${ }^{8}$

Roberts' assertion of the Legal Model failed to convince the Roosevelt administration. Later that year, Roosevelt was re-elected by a landslide and set about devising the" Court-packing Plan", officially The Judicial Procedures Reform Bill (1937). Under the guise of helping ageing Justices to cope with their workload, the bill would allow the President to nominate an additional new Justice for each current Justice who was seventy or older and chose not to retire. ${ }^{9}$ Had the bill passed, Roosevelt appointees would take over the Court and were expected to approve all the measures that had been struck down. However such a crude attempt to bend one branch of the federal government to the will of another caused great unease. Moreover, the Court signalled an about-face on the issue of government regulation of economic activity in West Coast Hotel v. Parrish (1937). There it reversed a recent precedent, Adkins v. Children's Hospital (1923), that had held a minimum wage law for women to be unconstitutional. ${ }^{10}$ Subsequent decisions confirmed that the Supreme Court had ceased to stand in the way of government economic regulation. As a result, the Court-packing Plan quietly faded away.

The tools that Owen Roberts and his colleagues employed in exercising "judgement" are familiar to all legal professionals. They include exploration of

8 United States v. Butler, 297 U.S. 1, 62-63 (1936).

9 William E. Leuchtenberg, The Origins of Franklin D. Roosevelt's "Court-Packing

Plan”, 1966 Sup. Cт. Rev. 347, 347-400 (1966).

10300 U.S. 379 (1937); 261 U.S. 525 (1923). 
the language of the Constitution and the intentions of those who wrote it; previous decisions of the courts on the same or similar issues - legal precedent; and respect for canons of judicial behaviour that ensure that courts do not not usurp powers assigned to other branches of government. In contrast to the Attitudinal model, Roberts denies that the Justices have any political or policy goals in play. Moreover, they only evaluate whether the statute fits with the Constitution and not whether it is good, effective or popular. For Roberts, the Constitution is Law and the Justices are expert legal analysts.

Fast forward some seventy years and another judge named Roberts is making the same point. In 2005, John G. Roberts, now Chief Justice of the U.S. Supreme Court, was undergoing confirmation hearings in the Senate. There he compared the role and motivations of Supreme Court Justices to umpires in a baseball game:

Judges and justices are servants of the law, not the other way round. Judges are like umpires. Umpires don't make rules, they apply them. The role of the umpire and the judge is critical. They make sure everyone plays by the rules, but it is a limited role. Nobody ever went to a ball game to see an umpire ... I have no agenda, but I do have a commitment. If I am confirmed, I will confront every case with an open mind. I will fully and fairly analyse the legal arguments that are presented. I will be open to the considered views of my colleagues on the bench. And I will decide every case based on the record, according to the rule of law, without fear or favour to the best of my ability. And I will remember that it's my job to call balls and strikes and not to pitch or bat. ${ }^{11}$

If liberal media reacted rather sceptically to Roberts' umpire analogy, it's important to note that liberal Supreme Court Justices share a similar view to Roberts of the Court's decision-making processes. Justice Stephen Breyer was appointed to the Court by President Bill Clinton in 1994 and has been a consistently liberal voter on the Court ever since. Yet he adheres to the Legal Model:

In my experience most judges approach and decide most cases, including constitutional cases, quite similarly. They are professionals. And their professional training and experience leads them to examine language, history, tradition, precedent, purpose, and consequences. Given roughly similar forms of legal education and professional experience, it is not surprising that judges often agree about how these factors, taken together, point to the proper result in a particular case. ${ }^{12}$

Similarly, the most liberal Justice of the current Court, Ruth Bader Ginsburg, said at her Senate Hearings:

Let me try to state in a nutshell how I view the work of judging. My approach, I believe, is neither liberal nor conservative. Rather, it is rooted in the place of the judiciary, of judges, in our democratic society. The

${ }_{11}$ Confirmation Hearing on the Nomination of John G. Roberts, Jr. to Be Chief Justice of the United States, 109th Cong. 55-56 (2005) (statement of John G. Roberts, Jr.,).

12 Stephen G. Breyer, Active Liberty 110 (2008). 
judiciary ... is placed apart from the political fray so that its members can judge fairly, impartially, in accordance with the law, and without fear about the animosity of any pressure group. As Judge Oliver Wendell Holmes counselled, 'One of the most sacred duties of a judge is not to read (her) convictions into the Constitution'. I have tried and will continue to try to follow the model Justice Holmes set in holding that duty sacred. ${ }^{13}$

So Ginsburg too denies the validity of the Attitudinal Model, arguing that it would entail the abandonment of a sacred duty. In fact virtually all judges and Supreme Court Justices insist they adhere to the Legal Model and, furthermore, insist that those who disagree with them on the Court also adhere to that Model. This leaves us with a predicament. If the Attitudinal Model is correct, and Law constitutes the surface form of decisions while politics is the substance, the Justices of the Supreme Court, both Liberal and Conservative, are either self-deluded or downright dishonest. And advocates of the Attitudinal Model do have ammunition for their conclusion. For whatever they say in their Opinions, Justice Ginsburg will almost always vote for a liberal result in a politically divisive case and Justice Thomas will almost always vote for a conservative result.

In fact, since the appointment of Justice Elena Kagan in 2010, the Justices of the Supreme Court divide perfectly along ideological-partisan lines. That is to say, every Justice appointed by a Democrat president has a more liberal voting record than every Justice appointed by a Republican president. ${ }^{14}$ This has never before been true. In recent decades, there has always been a Republican appointee, such as Justices Stevens and Souter, or a Democrat appointee, such as Justice White, who deserted the partisan-ideological bloc of their appointing president. This would suggest that the Presidents and Senators who treat Supreme Court appointments as a partisan-ideological process are achieving the goals they set themselves. Faced with such evidence, doesn't it strain credulity to argue for the baseball umpire version of political neutrality in legal and constitutional interpretation? Isn't it clear that when it comes to this context, Law and Politics constitute a distinction without a difference?

\section{INTERPRETIVE THEORY}

At this point, it is necessary to examine a more sophisticated form of the Legal Model, one that takes into account interpretive theory. For the U.S. Constitution requires interpretation and application in contexts unimagined by its Framers. The Constitution was conceived in the late eighteenth century, with key amendments being added in the Nineteenth and early Twentieth centuries. The challenge facing today's Justices can be readily illustrated by cases involving the Eighth Amendment's ban on "cruel and unusual punishments". What this meant at the time of its adoption in 1791 was unclear and Congressman Samuel Livermore of

13 Nomination of Ruth Bader Ginsburg, to Be Associate Justice of the Supreme Court of the United States, 103d Cong. 53-56 (1993) (statement of Ruth B. Ginsburg).

14 Neal Devins \& Lawrence Baum, Split Definitive: How Party Polarization Turned the Supreme Court into a Partisan Court, 2016 SuP. Cт. Rev. 301, 309 (2017). 
New Hampshire thought it was so vague as to be meaningless. He also added: “... it is sometimes necessary to hang a man, villains often deserve whipping, and perhaps having their ears cut off; but are we in future to be prevented from inflicting these punishments because they are cruel?"15 Livermore's words make two things clear: first, the meaning of the constitutional phrase was not clear at the time and, second, that eighteenth century notions of reasonable punishments would shock Americans two hundred years later. The search for an 'Original Meaning' is therefore difficult. More importantly, however, why would twenty-first century Americans allow themselves to be bound by an eighteenth-century definition of cruelty? The Court said as much in 1958 in Trop v. Dulles. There Chief Justice Earl Warren wrote that the meaning of the clause was not static and that "The Amendment must draw its meaning from the evolving standards of decency that mark the progress of a maturing society". ${ }^{16}$

Other key phrases in the Constitution are also vague - the "liberty" protected by the due process clauses of the Fifth and Fourteenth Amendments or the "equal protection of the laws" guaranteed by the Fourteenth Amendment. Moreover concepts of liberty and equality can change drastically over time. Such change can be rapid, as with the acceptance of gay and lesbian rights in recent years.

There is then a tension between the traditional approach of interpreting law - ascertaining and applying the original understanding and intention of those who passed a law - and the realistic need to ensure that law is free from anachronistic and unacceptable values.

This tension came fully to the fore in the Civil Rights era of the 1950s and 1960s, as politics and law became inextricable for all to see. The rights of black Americans, especially in Southern and border States, were being grossly violated by widespread de jure racial segregation. The Supreme Court had confronted this issue in Plessy v. Ferguson in 1896 and ruled by a vote of 8-1 that the $14^{\text {th }}$ Amendment equal protection clause was not violated by "separate but equal" treatment of whites and blacks. The "equal" part of the doctrine was always honoured in the breach and the Court began to take this aspect of the practice more seriously as time passed. ${ }^{17}$ By the time Brown v. Board of Education ${ }^{18}$ came before the Court in 1954, the Justices were prepared to break with the traditional interpretation. The historical evidence is persuasive that the Framers of the $14^{\text {th }}$ Amendment did not intend to prohibit racial segregation in schools. ${ }^{19}$ Yet the practice was so obviously discriminatory and racist to many Americans and, indeed, non-Americans, that it was a badge of shame. The Congress however was in no position to act, given the ability of Southern Senators and Congressmen to thwart attempts at reform.

The Supreme Court unanimously ruled that separate facilities were inherently unequal, but it did not attempt to justify this on originalist grounds. Instead, it stated cursorily that the evidence of the intent of the Framers was "inconclusive"

\footnotetext{
Furman v. Georgia, 408 U.S. 238, 262 (1972).

Trop v. Dulles, 356 U.S. 86, 101 (1958).

17 Missouri ex rel. Gaines v. Canada, 305 U.S. 337 (1938); Sweatt v. Painter, 339 U.S. 629 (1950); McLaurin v. Oklahoma State Regents 339 U.S. 637 (1950); Henderson v. United States, 339 U.S. 816 (1950).

18347 U.S. 483 (1954).

19 Raoul Berger, Government by Judiciary: The Transformation of the Fourteenth Amendment (2d ed. 1997).
} 
and attached more importance to the prevalence of public education for black Americans in 1954 compared to 1868. It then added some rather superficial sociological data about how segregated schools induced feelings of inferiority in black schoolchildren.

\section{The Warren Court And Social Reform}

While the Court made no statement regarding its change of interpretive method, a new path had been set by Brown. The Warren Court embarked on a series of path-breaking decisions that swept away de jure segregation. The successor Burger Court then extended its reach to de facto segregation. ${ }^{20}$ The Warren Court also broke new ground in areas such as the rights of accused, religious observance in schools, voting rights and pornography and free speech. This new interaction between constitutional law and political, social and cultural change brought about no less than a fundamental shift in the role of the federal courts in the American political system. The legal scholar Archibald Cox identified the change in his 1968 book entitled "The Warren Court: Constitutional Decision as an Instrument of Reform". Thus the Supreme Court, an institution that usually extolled continuity with the past, became a dynamic forum for radical change in America's legal and political order.

The genesis of the Brown decision owed much to the efforts of the National Association for the Advancement of Colored People (NAACP). Frustrated by racism in elected branches of government, the NAACP developed a litigation strategy in the 1920s and 1930s. The perceived successes of this strategy in Brown and other cases led more interest groups to follow suit. As Mark Tushnet noted, "The decades after Brown saw a proliferation of planned litigation campaigns". ${ }^{21}$ One of the most successful of these was that of the Women's Rights Project, founded by the American Civil Liberties Union in 1971. It achieved a series of important rulings from the Supreme Court in the 1970s and 1980s that greatly advanced the cause of women's equality. Symbolic of its importance was the appointment of one of its leading litigators, Ruth Bader Ginsburg, to the Supreme Court in 1993.

Another indicator of the new relationship between constitutional law and politics is the phenomenal increase in the number of amicus curiae briefs filed by interest groups and other political actors in the wake of Brown. In the decade spanning 1946-1955, there were 531 amicus briefs filed in cases granted review by the Supreme Court. By 1976-1985 that number had grown to 4,182, an increase approaching 800 percent. ${ }^{22}$ Clearly groups with political goals were now devoting considerable resources to exploiting the judicial path to success.

The decisions of the Warren and Burger Courts were liberal, sometimes radical. It is therefore no surprise that they generated a backlash from conservative politicians. In the 1968 presidential election, Republican candidate Richard Nixon

20 Swann v. Charlotte-Mecklenburg Bd. of Educ., 402 U.S. 1 (1971); Milliken v. Bradley, 418 U.S. 717 (1974).

21 Mark V. Tushnet, The NAACP.'s Legal Strategy Against Segregated Education, 1925-1950 168 (1987).

22 Joseph D. Kearney \& Thomas W. Merrill, The Influence of Amicus Curiae Briefs on the Supreme Court, 148 U. PA. L. Rev. 743, 752 (2000). 
criticised the Court for its decisions on criminal rights and other issues. ${ }^{23}$ Evangelical conservatives were stirred into political action by decisions on religious rights and, above all, abortion. As the Trump campaign and presidency illustrates, it is now standard Republican strategy to attack the Supreme Court's liberal decisions and to focus on Supreme Court appointments to reverse them.

The reaction in legal circles to the Warren and Burger Court's liberalism focussed less on ideology and more on interpretive methodology. While liberal activism was the consequence of the Warren Court Justices' approach to decisionmaking, it was the rise of what became known as the concept of the "living constitution" that was the cause. The Warren and Burger Court Justices were slow to articulate - or perhaps confess to - the change in the way that they were approaching constitutional interpretation. Just as it was left implicit in Brown, so too did Justice Blackmun's Opinion for the Court in Roe fail to state that the Court's use of a contemporary definition of liberty was the foundation of a woman's right to abortion. Justice Douglas's Concurring Opinion, however, made clear the 1970s feminist concept that lay behind the argument that a woman's liberty must encompass a right to abortion:

Elaborate argument is hardly necessary to demonstrate that childbirth may deprive a woman of her preferred lifestyle and force upon her a radically different and undesired future. (They may have) ... to endure the discomforts of pregnancy; to incur the pain, higher mortality rate and after effects of childbirth; to abandon educational plans; to sustain loss of income; to forgo the satisfactions of careers; to tax further mental and physical health in providing childcare; and, in some cases, to bear the lifelong stigma of unwed motherhood, a badge which may haunt, if not deter, later legitimate family relationships. ${ }^{24}$

In 1985 Justice William Brennan, a leading light of both the Warren and Burger Courts, candidly stated that the Constitution had to be interpreted through contemporary eyes:

We current Justices read the Constitution in the only way that we can: as twentieth Century Americans. We look to the history of the time of the framing and to the intervening history of interpretation. But the ultimate question must be, what do the words of the text mean in our time. For the genius of the Constitution rests not on any static meaning it might have had in a world that is dead and gone, but in the adaptability of its great principles to cope with current problems and current needs. ${ }^{25}$

23 Kevin J. McMahon, Nixon's Court: His Challenge to Judicial Liberalism and Its CONSEQUenCES, (2011).

24 Doe v. Bolton, 410 U.S. 179, 214-15 (1973) (Douglas, J., concurring). This is the companion case to Roe v. Wade. 410 U.S. 113 (1973).

25 William J. Brennan, Constitutional Interpretation, Address at Georgetown University, The Constitution of the United States: Contemporary Ratification (Oct. 12, 1985), reprinted in Alpheus Thomas. Mason \& Donald Grier Stephenson, American Constitutional LaW 607 (1987). 
Echoes of the concept of a "living Constitution" go back to the Framers themselves, Thomas Jefferson, Chief Justice Marshall and Woodrow Wilson, to name but a few. In the first place, the Constitution itself contains no prescription as to how it should be interpreted. Secondly, while few questioned originalism, it was often argued that original constitutional concepts had to be applied to new socio-economic situations that the Framers had not and could not have foreseen. And then, as noted above, there was the question of whether the Framers expected future generations of judges to be bound by their own understanding of highly generalised concepts.

\section{ROBERT BORK AND ORIGINALISM}

Critics of the Warren Court decried its activism. However, they abandoned judicial restraint per se as the main antidote and instead focussed on an interpretive method that they believed would enforce restraint: Originalism. Taking refuge in Originalism was, I believe, a strategic mistake. It offers an intuitive appeal, but is an impossibility to practice in the twenty-first century.

The intellectual leader of the Originalist movement was unquestionably Judge Robert Bork. In a seminal article in 1971, Bork argued that the Warren Court had not enforced values written into the Constitution, but rather had imposed its own value choices on the country. Not only could this not be squared with the presuppositions of a democratic society, but gave to the Court "an institutionalized role as perpetrator of limited coups d'etat". ${ }^{26}$

Bork argued that Brown could not rest on Warren's rationale. He nevertheless rescued it by claiming that while the intentions of the framers of the Equal Protection clause weren't clear on the issue of segregated schools, a reasonable interpretation would suggest a "no-state-enforced-discrimination rule". ${ }^{27}$ That aside, he produced a long list of twentieth century Supreme Court cases that had been wrongly decided because they were based on the Justices' choice of values rather than those contained in the Constitution as written and conceived. These included the creation of a right to privacy in the contraception case of Griswold v. Connecticut. ${ }^{28}$ As the Griswold privacy right also formed the basis of the right to abortion in Roe, then according to Bork, states could ban both contraception and abortion.

Bork said the Court also wrongly decided Shelley v. Kraemer. ${ }^{29}$ Here the Vinson Court had ruled that a state could not enforce a private racial covenant which banned selling a house to a black person. Bork, however, argued that the Fourteenth Amendment didn't reach private as opposed to state discrimination. $\mathrm{He}$

26 Robert H. Bork, Neutral Principles and Some First Amendment Problems, 47 IND. L. J. 1, 6 (1971).

27 Id. at 15. I have always detected a sleight of hand in Bork's Originalist justification, since if the framers did not intend to ban segregated schools - and they didn't - then that intention should have bound the Court. However, arguing that segregated schooling is constitutional and could only be eradicated by Constitutional amendment would have severely damaged the reception of Bork's broader thesis.

28381 U.S. 479 (1965).

29334 U.S. 1 (1948). 
then went on to attack the Warren Court's legislative reapportionment decisions ${ }^{30}$ which resulted in the principle of 'one person, one vote' being enforced:

Chief Justice Warren's opinions in this series of cases are remarkable for their inability to muster a single respectable supporting argument. The principle of one man, one vote was not neutrally derived: it runs counter to the text of the Fourteenth Amendment, the history surrounding its adoption and ratification, and the political practice of Americans from colonial times up to the date the Court invented a new formula. ${ }^{31}$

If Bork was correct, then states should be able to continue grossly mal-apportioning legislative districts unless either those same legislative districts decided to reform themselves or there was an amendment to the Constitution.

Bork offered originalism as an antidote to judicial activism, even if that meant judicial decisions that allowed policies that were unpalatable or even reprehensible to most Americans. However intellectually convincing his arguments, he was vulnerable to charges of tolerating numerous forms of racism, sexism and inequality. He paid the price for that in 1987, when President Reagan nominated him to the Supreme Court. Almost immediately Senator Edward Kennedy launched a blistering attack on the consequences of confirming Bork:

Robert Bork's America is a land in which women would be forced into back-alley abortions, blacks would sit at segregated lunch counters, rogue police could break down citizens' doors in midnight raids, schoolchildren could not be taught about evolution, writers and artists would be censored at the whim of government, and the doors of the Federal courts would be shut on the fingers of millions of citizens for whom the judiciary is often the only protector of the individual rights that are at the heart of our democracy. America is a better and freer nation than Robert Bork thinks... (President Reagan) should not be able to impose his reactionary view of the Constitution on the Supreme Court and the next generation of Americans. ${ }^{32}$

Given the Democrats' control of the Senate, Bork's fate was sealed. However, his ideas had already taken root in America's legal community, as witnessed by the rise of the Federalist Society. In its own words:

Founded in 1982, the Federalist Society for Law and Public Policy Studies is a group of conservatives and libertarians dedicated to reforming the current legal order. We are committed to the principles that the state exists to preserve freedom, that the separation of governmental powers is central to our Constitution, and that it is emphatically the province and the duty of the judiciary to say what the law is, not what it should be. ${ }^{33}$

\footnotetext{
Baker v. Carr, 369 U.S. 186 (1962); Reynolds v. Sims, 377 U.S. 533 (1964).

Bork, supra note 27, at 18.

100 CoNG. ReC. 18,519 (1987).

33 The Federalist Society, https://fedsoc.org/about-us (last visited Feb. 6, 2019 )
} 
The Federalist Society believes that the legal profession remains dominated by an "orthodox liberal ideology" and it is this legal order that must be overthrown. The Society may still see itself as a counter-revolutionary force in the legal profession, but it has succeeded in capturing the current United States Supreme Court. All five Justices that constitute the conservative majority - Roberts, Thomas, Alito, Gorsuch and Kavanaugh - are former members.

Another important force in championing Bork's Originalist theories was President Reagan's Attorney-General, Edwin Meese. Fittingly, in a speech before the Federalist Society on November 15, 1985, Meese launched a public campaign to promote a "Jurisprudence of Original Intention". ${ }^{34}$ Supported by other groups such as The Heritage Foundation, Meese brought considerable momentum to the Originalist cause. Of course he was also influential in identifying Supreme Court nominees and while he came to grief over the Bork nomination, a year earlier he had successfully promoted Antonin Scalia to the Court. Scalia tweaked Bork's Originalism to give greater weight to text rather than intention and blazed a trail on the Court for the next thirty years.

Scalia was an articulate and engaging advocate for his cause both on and off the Court. Like Robert Bork, he was prepared for his advocacy of Originalism to lead to results that would shock many contemporary Americans. For example, he argued that the Fourteenth Amendment's Equal Protection clause should not be read to require that women be given the vote. He approves of the fact that the battle for women's suffrage was conducted through politics and the passage of the Nineteenth Amendment. While he had no doubt that advocates of the Living Constitution would find the right of women to vote in the Equal Protection clause, that was not the language nor the intention of the clause. ${ }^{35}$

Given that Scalia would not read women's right to vote into the Equal Protection clause, it comes as no surprise that claims for gays and lesbians, either in Due Process or Equal Protection cases, received short shrift from him. Indeed, his dissenting Opinion in Lawrence v. Texas brought together the views of Robert Bork and the Federalist Society with his own. Lawrence held that a Texas statute criminalising same-sex sexual activity violated the Constitution. Scalia wrote:

Today's opinion is the product of a court, which is the product of a law-profession culture, that has largely signed on to the so-called homosexual agenda, by which I mean the agenda promoted by some homosexual activists directed at eliminating the moral opprobrium that has traditionally attached to homosexual conduct...

One of the most revealing statements in today's opinion is the Court's grim warning that the criminalization of homosexual conduct is 'an invitation to subject homosexual persons to discrimination in both the public and in the private spheres'. It is clear from this that the Court has taken sides in

34 Edwin Meese, The Great Debate: Attorney General Ed Meese III, The Federalist SocIETy (Nov. 15, 1985), https://fedsoc.org/commentary/publications/the-great-debateattorney-general-ed-meese-iii-november-15-1985.

35 Antonin G. Scalia, A Matter of Interpretation: Federal Courts and the LaW, 47 (1997). 
the culture war, departing from its role of assuring, as neutral observer, that the democratic rules of engagement are observed. ${ }^{36}$

Scalia goes on to emphasise that he has no objection to homosexuals pursuing their goals through the democratic processes. But changes in such laws as the one at issue should be chosen by the people and "not imposed by a governing caste that knows best". ${ }^{37}$

\section{IMPaSSE AND A Possible WAy ForWARd}

It should be clear that the relationship between politics and law lies at the heart of the Supreme Court today as never before. Conservative Justices, championing Originalism, accuse liberal Justices of imposing their political preferences on a democratic people. Liberal Justices allege that conservative Justices are imprisoning the people in the past and failing to acknowledge the importance of political and social change.

Academic champions of the Attitudinal Model assert that both conservative and liberal Justices are dissembling and that they camouflage their decisions in legal paraphernalia, while advancing their political goals. And other actors in the political system - presidents, members of Congress, interest groups, the media treat the Court and the Justices as thoroughly politicised.

The situation is now at an impasse and the debates are locked in. It seems inevitable that there will be more unseemly nomination battles of the Gorsuch and Kavanaugh varieties. Supreme Court retirements will be thoroughly strategic, as Justices seek to create a vacancy when a president and Senate majority will replace them with a Justice of similar ideology and approach to interpretation. Whatever else they had in mind, the Framers of the Constitution did not envisage that the Supreme Court would fall so low.

Of course, there are those who refuse to give up. A recent public spat between President Trump and Chief Justice Roberts was revealing. Trump railed against a U.S. District Court judge, Jon S. Tigar, who held that Trump could not refuse to process asylum claims by those who had entered the United States illegally. Trump accused Tigar of political bias by damning him as "an Obama judge". Chief Justice Roberts responded by saying:

We do not have Obama or Trump judges, Bush judges or Clinton judges. What we have is an extraordinary group of dedicated judges doing their level best to do equal right to those appearing before them. That independent judiciary is something we should all be thankful for. ${ }^{38}$

If the Chief Justice is to convince his various audiences, both liberal and conservative judges will need to change tack. Perhaps the best way forward for the Justices of the

Lawrence v. Texas, 539 U.S. 558, 602 (2003).

Id. at 604 .

38 Adam Liptak, Chief Defends Judicial Independence After Trump Attacks 'Obama Judge', N.Y. Times, Nov. 21, 2018, at A1. 
Supreme Court would be to return to the practice of judicial self-restraint. Theories of judicial role have been side-lined by the debate over interpretive method. However, in the twentieth century, some of those regarded as among the greatest judges in American history have argued the case for - and practised - judicial selfrestraint. These "greats" include Judge Learned Hand and Supreme Court Justices Oliver Wendell Holmes, Louis D. Brandeis, Felix Frankfurter and John Marshall Harlan II. ${ }^{39}$ In one case, Justice Brandeis developed his Ashwander Rules, designed to limit the scope of the Court to declare legislation unconstitutional. ${ }^{40}$ Holmes warned Justices against reading their policy predilections into general concepts and language in the Constitution with the memorable line that: "The Fourteenth Amendment does not enact Mr Herbert Spencer's Social Statics". ${ }^{41}$ However, while these great liberal judges advocated restraint, they did not foreclose identifying rights in the Constitution that the Framers had not intended. Justice John Marshall Harlan II, frequently a dissenter on the Warren Court, nevertheless recognised that the due process clause of the Fifth and Fourteenth Amendments could encompass new rights. His most famous elaboration of his views came in Poe v. Ullman in 1961. The case involved a challenge to Connecticut's statute criminalising the use of contraceptives by married couples. The Court majority dismissed the case on grounds of justiciability, but Harlan dissented and argued that the statute was unconstitutional. While he made clear that not all state morals legislation should be overturned, he held that there was an unspecified constitutional right to privacy and it was not static. ${ }^{42}$

Later Courts powered ahead with the right to privacy and declared rights to abortion and same-sex marriage. But liberal Justices returned to Harlan's vision in a case involving physician-assisted dying. Washington $v$. Glucksberg ${ }^{43}$ involved a state prohibition of assisted suicide and a challenge to that ban based on a due process liberty claim. The Supreme Court unanimously upheld the statute, but concurrences by the liberal Justices held that the situation might evolve to a point where the Court might reconsider. Justice Souter, for example, cites Harlan's dissent in Ullman frequently and in detail, before concluding that the state ban was not arbitrary. Souter describes the claimed right to physician-assisted suicide as an 'emerging issue' and that "The Court should accordingly stay its hand to allow reasonable legislative consideration. While I do not decide for all time that respondents' claim should not be recognized, I acknowledge the legislative institutional competence as the better one to deal with that claim at this time". ${ }^{44}$

The value of Souter's approach in Glucksberg was underlined when, in 2008, the voters of Washington approved ballot initiative 1000, which became the

39 Learned Hand was a federal judge considered twice for appointment to the Supreme Court. His contemporaries were in no doubt that he was a great judge who deserved a position on the highest court. Jerome Frank wrote: "Many who have written of Learned Hand have lamented the fact that he did not become a Supreme Court Justice, a post for which no-one else has ever been so well fitted". Jerome N. Frank, Some Reflections on Learned Hand, 24 U. ChI. L. Rev. 666, 669 (1957).

40 Ashwander v. Tennessee Valley Auth., 297 U.S. 288 (1936).

41 Lochner v. New York, 198 U.S. 45, 75 (1905).

42 Poe v. Ullman, 367 U.S. 497, 522-55 (1961).

43521 U.S. 702 (1997).

$44 \quad I d$. at 789. 
Washington Death with Dignity Act. The debate had continued after Glucksberg, the full political process had been invoked and the people had decided. This was surely a better outcome than if the U.S. Supreme Court had imposed its will on the people of Washington and indeed the rest of America.

If liberals Justices should hold back from taking the lead in settling controversial, emerging claims, conservatives should abandon the historic stranglehold of Originalism. It is worth reminding themselves that Originalism was first and foremost a means of preventing excessive judicial activism. There is a middle way between a rigid Originalism and 'government by judiciary'. Justice Scalia, for example, has scoffed at the Trop approach to adjudicating Eighth Amendment 'cruel and unusual punishments' claims: namely that the Court employ the criteria of "evolving standards of decency that mark the progress of a maturing society". 45 Yet, in the death penalty case of Roper v. Simmons ${ }^{46}$ in 2005, his dissent offered a reasonable way of applying the Trop criteria. Roper involved a challenge to a Missouri statute that allowed the execution of 17 year-olds for aggravated murder. A 1988 precedent held that those under 16 years of age could not be executed. However, the following year, in Stanford v. Kentucky, the Court ruled that 17 yearolds could be put to death. ${ }^{47}$

The Missouri Supreme Court held that national opinion on juvenile execution had changed since Stanford. Accordingly, both Justice Kennedy's Opinion for the Court and Justice Scalia's dissent canvassed state laws on the age at which juveniles could be executed. For Scalia that canvass should have been dispositive, while Kennedy also took account of the Justices own evaluation of cruelty and international norms. The Court divided 5-4 on the issue, but that does not mean that Scalia's approach of deciding the issue based on 'objective indicia' was not a valid or, indeed, reasonable one.

There is, then, a middle ground between Originalism and Living Constitutionalism that once existed and could exist again. That would involve conservative Justices accepting that the meaning of constitutional language does change over time, as society changes. It would also involve liberal Justices staying their hand on issues and allowing the democratic process to prevail except in cases where there is a clear constitutional violation.

This is turn would change the relationship between politics and constitutional law in the United States and equally important, lower the political profile of the Supreme Court. How likely is this to happen? Chief Justice Roberts has made it very clear that he would welcome such a change, but there must be considerable doubt as to whether Justices on either side are willing to do what is required. That said, the Chief now sits in the ideological centre of the Court and is well-placed to lead it away from its current political and legal turmoil. Alternatively, he may join the other four conservative Justices and reverse many of the liberal decisions of recent decades, including abortion rights and gay rights, and in contrast promote the rights of religious adherents and big business. If he chooses the latter, the relationship between politics and law can only become ever more combustible.

SCALIA, supra, note 36 , at 46.

543 U.S. 551 (2005).

47 Thompson v. Oklahoma, 487 U.S. 815 (1988); Stanford v. Kentucky, 492 U.S. 361 (1989). 